\title{
Ensaio sobre a Cegueira e a narrativa fílmica: (Re)Visões de um olhar sobre um mesmo texto
}

\author{
Jerzuí Mendes Torres Tomaz \\ Professora Doutora da Universidade Federal de \\ Alagoas (Ufal); Programa de Pós-graduação em \\ Letras e Linguística (PPGLL). \\ jerzuitomaz@hotmail.com
}

\section{IzaBel BRAndão}

Professora Doutora da Universidade Federal de Alagoas (Ufal); Programa de Pós-graduação em Letras e Linguística (PPGLL); Pós-doutorado em Estudos Literários pelo Programa de Estudos Literários da Universidade Federal de Minas Gerais (UFMG) e pesquisadora do CNPq. ifob@oi.com.br

Resumo: Este artigo faz um estudo do romance Ensaio sobre a cegueira (1995), do escritor português José Saramago, transformado em filme pelo cineasta brasileiro Fernando Meirelles, em 2008, com o título de Blindness, a partir de uma perspectiva crítica interdisciplinar, que propõe uma leitura da tradução/transposição da narrativa ficcional para a narrativa fílmica. O olhar crítico proposto passa pelo diálogo entre as teorias do cinema e da psicanálise, visando a uma compreensão das questões postas no romance e trazidas para o filme, pela via da cultura e de gênero sem, contudo, buscar um enquadramento formal do enfoque analítico numa única teoria ou perspectiva.

Palavras-chave: Literatura e Cinema; Saramago e Meirelles; Crítica literária e interdisciplinaridade

\section{Almir Guilhermino}

Professor Doutor da Universidade Federal de Alagoas (Ufal), do Curso de Comunicação Social da UFAL; Pós-doutorado Antropologia Visual pela Universidade do Minho, Portugal. almirguilhermino@gmail.com

Abstract: This essay deals with the novel Ensaio sobre a cegueira (1995), by the Portuguese writer José Saramago, transformed into the movie Blindness, by the Brazilian movie director Fernando Meirelles, in 2008, from an interdisciplinary critical perspective, which proposes a reading of the translation/transposition of the fictional narrative into a filmic one. The critical perspective proposes a dialogue between the theories of cinema and psychoanalysis aiming at an understanding of the issues stemming from the novel and brought to the film, through culture and gender without, however, framing the analytical approach within a single theory or perspective.

Keywords: Literature and Cinema; Saramago and Meirelles; Literary Criticism and Interdisciplinarity 

Se podes olhar, vê. Se podes ver, repara.

José Saramago

Sabe-se, desde a edificação da psicanálise, que a pulsão escópica ou escopofílica encontra-se vinculada ao saber e, consequentemente, ao poder ou domínio do sujeito cognoscente sobre o mundo. A obra literária Ensaio sobre a cegueira (1995), transformada em filme em 2008 pelo diretor brasileiro Fernando Meirelles, do prêmio Nobel de Literatura José Saramago, primeiro escritor de língua portuguesa a receber tal título, traz à cena, entre outros aspectos, uma imagem assustadora e sombria do humano, o que o aproxima de Franz Kafka, Albert Camus, Elias Canetti, Primo Levi, só para citar alguns expoentes da arte literária, e lança luz sobre o vínculo perverso que se insinua na relação com a alteridade.

Vale lembrar uma outra narrativa que traz a mesma temática: William Golding, autor inglês, vencedor do Nobel de literatura de 1983, escreveu o romance Lord of the Flies (1954, também transformado em filme por duas vezes: em 1963 e em 1990), que pode ser considerado uma distopia, no mesmo sentido que Ensaio sobre a cegueira. $\mathrm{O}$ romance de Golding mostra um grupo de crianças e adolescentes cujo avião, em rota de fuga da Segunda Guerra Mundial, cai numa ilha deserta do Pacífico Sul. Num ambiente aparentemente edênico, o que poderia ser uma colônia de férias para as crianças envolvidas na história, apresenta-se como a desestruturação e deterioração da sociedade (a mesma que está em conflito fora da ilha), uma vez que os meninos dividem-se em dois grupos rivais, que brigam pela liderança. Um dos grupos, liderado por Ralph, busca manter-se dentro das regras de uma democracia civilizada, enquanto o outro, liderado por Jack, reverte-se na barbárie, passando a agir fora do chamado pacto civilizatório. O contexto de deterioração dessa sociedade representada na ilha leva à morte e ao 
${ }^{1}$ A compreensão desse termo deu-se durante os estudos de doutoramento de Jerzuí Mendes Torres Tomaz sobre a escritora gaúcha Lya Luft. A tese intitulada "Marcadores afetivos e inscrições corporais no universo feminino de Lya Luft", defendida em 2007, no Programa de Pós-Graduação em Letras e Linguística da Universidade Federal de Alagoas, foi transformada em livro (Corpo e afeto na escrita de Lya Luft) e publicada pela Edufal em 2009. O termo em questão aponta para a transitoriedade da identidade do sujeito no mundo contemporâneo. sacrifício humano, com a morte de uma das crianças em uma "guerra" que só terminaria na destruição total da ilha, incendiada pelas crianças, não fosse a chegada de um navio de guerra, cujo capitão as resgata, levando-as de volta ao seu estado "civilizado". A pergunta que o/a leitor/a faz é que, ao final da narrativa, o navio que resgata o grupo é um navio de guerra: quem o salvará dela, quando novamente em alto mar?

As narrativas de Golding e de Saramago trazem nos seus contextos distópicos, uma luz diferenciada para a reversão à barbárie. $\mathrm{O}$ autor inglês coloca a desesperança e a derrocada social em crianças, cujo psiquismo revela a imensa fragilidade e desamparo do ser humano diante de uma situação-limite. Já o autor português traz, no contexto da cegueira, uma possibilidade de saída a partir do olhar (literal e simbólico) da mulher, mas os adultos, que se deterioram diante de uma situação-limite, matam e estupram deliberadamente. Os meninos de Golding têm uma espécie de licença, exatamente por serem crianças, e por não disporem de uma orientação supostamente madura dos adultos, ausentes da ilha.

Denota-se que toda estrutura civilizatória elege os seus outros e, a partir disso, os segrega e/ou silencia. O universo temático de Saramago retoma a matéria ficcional da solidão/desamparo humano, representado por meio do sentido da busca, da errância, do incessante rastreamento do que seria a identidade humana. Destituídos de uma história e de um passado, envoltos numa significativa anomia, as personagens do romance citado - o médico, a mulher do médico, a rapariga de óculos escuros, o rapazinho estrábico, o primeiro cego, o velho com a venda preta - encarnam a voz dos des-centrados, exilados de corpo e de alma, possibilitando que se afirme que o projeto literário do autor português encontra-se marcado pelo signo da "estrangeiridade", característica do que se denomina estéticas do deslocamento ${ }^{1}$, já que discorre 
sobre o imigrante/exilado, aquele que está deslocado das narrativas que poderiam inseri-lo.

Vê-se que Saramago, ao urdir uma fábula sobre uma epidemia de cegueira, aponta para a fragilidade da chamada civilização e destaca, por meio de uma prosa singular, o tema da dignidade humana como eixo central de sua criação romanesca. Deve-se mencionar que o colapso civilizatório é tema recorrente na escrita do autor. Em As intermitências da morte (2005), narrativa prenhe de humor e ironia, uma nação encontra-se prestes a se desestabilizar, quando "a grande dama" suspende ali suas atividades. A vida eterna, antes tão desejada, põe em estado caótico hospitais, agências de seguros, casas funerárias, asilos, famílias, o Estado e finalmente a Igreja, uma vez que sem morte inexiste ressurreição e, sem ressurreição, não há lugar para a influência da Igreja.

Por meio de uma experiência imaginativa única, Saramago convida a uma reflexão acerca da urgência de se resgatar o afeto perdido, que se contrapõe à indiferença/ abstinência ética e abre espaço para as inúmeras formas de violência que povoam o mundo contemporâneo.

O escritor de Azinhaga recusou, inicialmente, a adaptação da obra em estudo para o cinema e, ao fazêlo, realizou um desejo de Fernando Meirelles, o diretor brasileiro, conhecido por Cidade de Deus (1999), que também tentou convencer o escritor a lhe vender os direitos do livro, em 1997. Niv Fichman, produtor de cinema canadense, não foi o primeiro a propor adaptar o romance de Saramago para o cinema. Diversas consultas lhe foram feitas, até que ganhou o Canadá. Fichman convidou o roteirista Don McKellar, que fez seu trabalho sem saber quem cuidaria da direção. Quase 10 anos depois, esse roteiro chegou às mãos de Meirelles, junto com o convite de Fichman para dirigir Blindness. ${ }^{2}$ Não se sabe ao certo porque por que os canadenses escolheram Meirelles para dirigir o filme. Talvez o seu interesse pelo

\author{
${ }^{2}$ Para demarcar a \\ diferença entre romance \\ e filme, optamos por \\ usar o título do romance \\ de Saramago em \\ português e a narrativa \\ fílmica, pelo título \\ original, em inglês.
}


${ }^{3}$ Cf.Saramago $<<$ http:// blogdeblindness.blogspot. com.br/>> Acesso em 21 de novembro de 2009. romance e o fato de o português ser sua língua materna facilitassem a compreensão da linguagem de Saramago. É importante observar que os filmes do diretor brasileiro nada têm a ver com o realismo quase que fantástico de Saramago, mas Meirelles aceitou o desafio. As filmagens começaram um ano depois, com uma única exigência do escritor: manter a atemporalidade da obra. Meirelles, então, decidiu rodar a película em grandes cidades como São Paulo, Toronto e Montevidéu, com o propósito de confundir a localização temporal da história e universalizar a epidemia de cegueira.

As inquietações do diretor brasileiro foram tantas que decidiu postar, em seu blog, as anotações de um diário. ${ }^{3}$ Quem acessou o blog de Blindness viu um diretor em conflito e, em alguns momentos, revelando-se incapaz de transpor a história contada em frases e períodos para o cinema, que narra através de planos e de cenas. O blog serviu-lhe de amparo, quando o filme estreou e foi recebido com apatia pelo público e pela crítica, na 61ª edição do Festival de Cannes. Percebe-se que tanto o espectador quanto muitos roteiristas e diretores ignoram que a literatura conta e o cinema mostra. Nesse mostrar, o tempo se transforma em temporalidade e o espaço, em espacialidade, como pondera Christian Metz e Roland Barthes, dois apaziguadores do confronto estabelecido pelo espectador diante de um filme adaptado, extraído, inspirado ou baseado num texto literário.

De acordo com Meirelles, quando Saramago representa a cegueira em seu romance, não se trata de cegueira física e sim, psicológica e ideológica, já que

Num mundo onde as imagens desapareceram, as aparências perdem a relevância. Revela-se o que está por baixo. Dentro dessa ideia de sermos reduzidos a instintos básicos, uma possível sinopse para o filme seria 'uma história sobre a perda e o 
reencontro da humanidade em cada um de nós' (MEIRELLES, apud ARANTES, 2008, p. 6).

É possível dizer que, no sentido posto pelo diretor, o espaço de recuperação da "humanidade em cada um de nós", o retecimento do lugar do afeto, coloca-se a partir da perda do sentido da visão. É preciso que se perca algo de muito precioso para que se aprenda o seu valor, devendo-se buscar, principalmente, no retecimento das relações a recuperação desse algo perdido. Quando a visão das personagens é recuperada, no filme, o narrador, o velho cego de um olho só, uma representação que pode muito bem ser associada a uma espécie de Tirésias ${ }^{4}$ contemporâneo, informa que a mulher do médico, única que enxergava durante a epidemia de cegueira, desejou estar cega... Na recuperação dos outros, ela, que detinha um poder quase de vida e morte sobre todos, volta a ser alguém comum, sem nada que a diferenciasse das outras pessoas, como antes. Nesse sentido, é possível dizer que a mulher do médico, enquanto detentora da visão e do cuidado dos exilados, acaba por assumir um papel que a aproxima da imagem de Shekinah (representante feminina de Deus no Talmud), especialmente pelo ato de cuidar, maternando, de certa forma, os habitantes do inferno da cegueira. É a boa mãe em oposição à mãe terrível de que fala a mitologia. Como o outro feminino de Deus, ela tudo vê, tudo sabe. ${ }^{5}$ Ao tornar-se igual a todos, perde o seu componente de divindade.

Uma cena do filme que pode ilustrar esse senso de perda equivalente à noção de desamparo, acontece quase ao final da história quando avistamos, em Primeiríssimo Plano, o médico e sua mulher saindo pelas portas do supermercado, e um outdoorna rua traz a imagem de outro olhar feminino em close-up, como se ilustrasse o famoso provérbio "Em terra de cego, quem tem um olho é rei". Nesse momento o cão das lágrimas entra em cena: pelo
${ }^{4}$ A mitologia da Grécia antiga ensina que Tirésias, cegado pelos deuses por saber demais, tinha o dom da profecia, "a visão correlata do terceiro olho" (CAMPBELL, 1987, p.27), tendo conhecimento de dois mundos, o masculino e o feminino, pois, em suas existências (sete ao todo), havia tido a oportunidade de vivenciá-los da mesma forma. A narrativa de Saramago mostra a personagem cega de apenas um olho, uma forma metafórica de mostrar o conhecimento (a sabedoria) através de uma pessoa velha que vê por um olho e não vê pelo outro, mostrando a possibilidade da associação com o sábio grego.

${ }^{5}$ Cf. Neuman (1963, p.80; 246, 330) para mais informações sobre Shekhinah. 
olhar desolado da mulher do médico, Meirelles mostra vários cães devorarem as entranhas de um cadáver. $\mathrm{Na}$ sua diferença, o cão das lágrimas buscou aproximar-se do humano, ao lamber o pranto da mulher do médico. Aqui, o desamparo humano mostra-se como equivalente ao animal: um come e mostra o humano no limiar da morte, e o outro lambe a vida, representada pela mulher do médico e por suas lágrimas.

Esse momento é aprofundado quando, para se proteger da chuva, a mulher do médico entra em uma igreja. Podemos perceber, aqui, que o trânsito entre as linguagens literária e cinematográfica confronta diferenças. A cegueira da narrativa literária é transposta para a película pelas imagens e esculturas vendadas no interior da igreja. A chave do núcleo semântico no filme é revelada através do sermão do padre: a cegueira não é uma punição de Deus, já que Ele não age de tal forma. A parábola de São Paulo ilustra a ação: "Paulo matava e perseguia cristãos, mas o Senhor foi até ele e o converteu. Ele o converteu pela cegueira. É isso que acontece conosco". Essa parábola traduz a metáfora que ensina que a cegueira talvez tenha sido a solução para a humanidade repensar seus conceitos. Em entrevista a um jornal português, José Saramago disse que o ideal seria que todos fôssemos cidadãos ativos, mas estamos ocupados demais com os nossos problemas e com a conquista da própria felicidade. "Estamos sempre mais ou menos cegos", disse.

O romance nos alerta para o fato de que a barbárie pode ser universal, abismo ético que espreita a tênue linha que separa o estado de civilização e a possibilidade de quebra do pacto civilizatório. O próprio escritor propõe que a estupidez humana não tem limites, não diferencia cegos e videntes, pois

A história da humanidade é um desastre contínuo. Nunca houve nada que se parecesse com um momento de paz. Se ainda fosse só a guerra, em 
que as pessoas se enfrentam ou são obrigadas a se enfrentar... Mas não é só isso. Esta raiva que no fundo há em mim, uma espécie de raiva às vezes incontida, é porque nós não merecemos a vida. Não a merecemos. Não se percebeu ainda que o instinto serve melhor aos animais do que a razão serve ao homem (SARAMAGO, 2008, p. 5).

O posicionamento do literato se coaduna com os postulados de Sigmund Freud, no que se refere ao dualismo pulsional e à necessidade de algo que barre as pulsões agressivas que habitam o humano. A Kultur seria, pois, o resultado, sempre precário, da tentativa de se entrelaçar Eros e Ananké (amor e necessidade), de colonizar o narcisismo das pequenas diferenças e induzir o sujeito à renúncia pulsional por meio do sentimento de culpa e, na melhor das hipóteses, através da via sublimatória, questões largamente debatidas ao longo de O mal-estar na civilização (1976).

Deduz-se que o imperativo cultural superegóico "Ama a teu próximo como a ti mesmo"6 (FREUD, 1976, p. 168) coloca-se como a defesa mais potente contra as silenciosas pulsões de morte, mas, como indaga o próprio fundador da psicanálise, quem poderá garantir que o ruidoso Eros poderá derrotar Tânatos, seu incansável adversário?

O entrelaçamento entre vida e morte, dor e gozo, relaciona-se com a posição do perverso, o grande mestre do gozo, escandalosa descoberta do saber psicanalítico, uma vez que a psicanálise põe em xeque a fronteira entre a perversão e a dita "normalidade". A própria etimologia da palavra perversão - oriunda de perversidade e carregada de um sentido moral e religioso - relança a temática da duplicidade humana, da moral insana que pode querer o bem, mas fazer o mal.

Na teorização de Slavoj Zizek, "o perverso é um sujeito que assume directamente o paradoxo do desejo

\footnotetext{
${ }^{6}$ A demarcação dessa referência é interessante por remeter às Tábuas da Lei mosaica, onde o estabelecimento de uma normatização de comportamento mais do que fundar um pressuposto religioso, funda, em última análise, o estabelecimento de uma conduta básica da moral civilizatória. Cf. Marcos, 12:30-31.
} 
e inflige dor tendo em vista permitir o gozo, introduz o cisma tendo em vista propiciar a união, e assim por diante" (ZIZEK, 2006, p. 45). Tal percepção pode ser ilustrada ao longo do filme, mas especialmente a partir do estupro coletivo, que será comentado em momento adequado.

De qualquer modo, constata-se que a estrutura perversa vai nos confrontar com a instância do excesso, da desmedida, da irrupção de uma força interior que se impõe, seja no sentido em que o objetivo da ação é perverso - sadismo, masoquismo, exibicionismo e fetichismo -, ou naquelas situações em que o objeto de satisfação sexual é perverso - pedofilia, zoofilia, auto-erotismo (KRAFFTEBING, 1990 apud JULIEN, 2002, p. 103).

Retomando Ensaio sobre a cegueira, deparamonos com metáforas como "mar de leite", "brancura insondável", "cegueira branca", "glória luminosa" em contraponto a um persistente mecanismo de recusa (próprio da perversão; ver e negar, ou seja, denegar) em ver aquilo que se oferece aos olhos: confinamentos em condições desumanas, estados precários de higiene e alimentação, disputa por alimentos, luta pelo poder e, por fim, violência desmesurada que conduz a estupros coletivos e à morte. Nesse sentido, personagens confinados em espaços heterotópicos (FOUCAULT, 1984) desvelam o contexto da perversão, a partir da autorização social que confina pessoas numa "prisão" regulada pela lei. A prosa de Saramago desnuda, impiedosamente, o horror da banalidade do mal, em um mundo no qual o impossível deixa de existir.

No filme de Meirelles, uma das cenas que revela essa visão nos mostra uma espécie de negociação (de algo inegociável que é a liberdade das mulheres de escolherem com quem e quando elas desejam fazer sexo), que envolve a troca de sexo por comida: ou as mulheres se prestam à troca ou não haverá comida para ninguém. $\mathrm{O}$ médico, voz de autoridade destituída porque não conseguiu curar 
ninguém da epidemia de cegueira, tendo sido ele mesmo contaminado, diz que é à mulher que cabe decidir se aceita o estupro ou não, como se isso fosse uma questão de decisão e escolha. É quando o diretor coloca todas as mulheres na posição de "voluntárias", porque todos precisam comer. A comida que mata a fome física é obtida à custa da violação da dignidade das mulheres, que são estupradas até a morte de uma delas. Um dos pontos de vista da cena ocorre a partir do olhar da mulher do médico, a única a ver tudo como testemunha ocular da violência. Do lado de cá da tela, somos espectadores/as de uma cena que pode ser vista a partir do que afirma Laura Mulvey (2009 [1975], p.19): "o olhar, prazeroso na forma, pode ser ameaçador no conteúdo, e é a mulher como representação/imagem que cristaliza tal paradoxo". $\mathrm{O}$ prazer do olhar aqui é substituído pela ameaça. O paradoxo está em que a mulher do médico nada pode fazer diante da verdade que apenas ela vê e do silêncio que deve manter diante de tudo o que ocorre, sob pena de destruir o pouco que ainda pode fazer nesse território de guerra e desumanidade em que está obrigada a viver.

No contexto literário cuidadosamente elaborado por Saramago, o surto epidêmico de cegueira sem causa determinada, diagnosticado como "mal-branco" ou "brancura luminosa", incide sobre a responsabilidade de se ter visão quando os outros a perderam. O narrador-Tirésias nos informa que a mulher do médico, única a permanecer vidente, "desejou estar cega também, atravessar a pele visível das coisas e passar para o lado de dentro delas, para a sua fulgurante e irremediável cegueira" (SARAMAGO, 1995, p. 65). Nesse sentido, o/a leitor/a pode compreender o que acontece como se nos fosse dito que é melhor não ver a realidade, porque como ela se mostra para quem vê é o caos. Aqui, podemos filtrar da película de Meirelles a cena dos estupros coletivos em que essa mulher mata o líder do pavilhão três e é percebida pelo cego de verdade, 
${ }^{7}$ Câmera em movimento acompanhando, por exemplo, o andar dos atores, na mesma velocidade. Também, qualquer deslocamento horizontal da câmara. que sabe se guiar por aquela terra de ninguém, através de sua percepção de um universo já conhecido - a cegueira para ele tem outra dimensão, uma vez que ele não a "pegou" na epidemia -, usa bengala e "conta" os ganhos por comida como nenhum outro personagem o faria.

Ainda no tocante aos estupros coletivos, o filme mostra as mulheres cegas que caminham em fila indiana, rumo ao pavilhão três. A cena é bastante similar à do livro, mas tem a especificidade de uma produção cinematográfica que cuida de mostrar, através da câmera, o acompanhamento dessas mulheres com o recurso do travelling $g^{7}$ por detrás das grades do corredor e, depois, através da captação de suas sombras imersas em um fundo branco, o que confere um olhar inovador à cena. O mesmo recurso da câmera em travelling é utilizado posteriormente, na cena já comentada da morte do líder do pavilhão três, quando a mulher do médico dirige-se com a tesoura rumo àquele pavilhão. Seu trajeto é mostrado pelo bater da tesoura contra as grades, enquanto ela desce as escadas e depois, no retorno, atravessa o corredor com os vidros manchados de sangue.

É digno de nota que a desagregação dos laços sociais é representada plasticamente, no filme de Meirelles, por intermédio de referências, na construção dos cenários, a diversos pintores como Francis Bacon (desconstrução das imagens, fadings), Lucien Freud (incidência do horror, do nu, do grotesco), Hieronymus Bosch (desorganização relacional: criança/adulto, homem/mulher, gente/bicho), Rembrandt (estruturação dos enquadres de cenas e recorrência de paisagens em ruínas), Malevitch, além de dadaístas, cubistas, sem excluir as gravuras japonesas. Aqui se pode destacar o quadro "Parábola dos Cegos", de Pieter Bruegel, uma vez que a narrativa de Saramago faz uso desse recurso à parábola e que a película de Meirelles explora em várias cenas.

Em termos discursivos, essa desagregação se manifesta na fala da rapariga de óculos escuros que se 
dirige à mulher do médico, quando esta assassina o chefe de uma quadrilha (o autoproclamado "rei" do pavilhão três) que, de dentro do manicômio onde todos estão confinados, rouba comida, extorque dinheiro e estupra mulheres: "Não se acuse, foram as circunstâncias, aqui todos somos culpados e inocentes, muito pior fizeram os soldados que nos estão a guardar, e até esses poderão alegar a maior de todas as desculpas, o medo" (SARAMAGO, 1995, p. 101 - grifos nossos).

O "rei" do pavilhão três, que detém um revólver com o qual ameaça a todos, lidera um lugar que representa a desordem e a violência, o cúmulo da degradação e desumanização, é quem comanda os roubos e os estupros coletivos, numa possível referência ao imperialismo colonizador que, em nome do poder, disseminou a morte e a violência no espaço colonizado. No caso do filme, esse espaço heterotópico é território de ninguém, ou, nos termos de Foucault (1984), lugar de nenhum lugar; além de ser também demarcatório de um "não-lugar", como nos ensina Marc Augé (1992). Os personagens da narrativa de Saramago são transeuntes que precisam reorganizar temporariamente esse espaço onde se encontram, buscando ali constituir provisoriamente uma identidade para si mesmos, tornando, na medida do possível, esse espaço num "lugar do afeto", onde podem se reconhecer como sujeitos. Essa percepção do "nãolugar" não se fecha apenas no espaço do manicômio, como é o caso dessa narrativa. É possível construir nesse espaço um "lugar", com a dimensão do afeto inserida pelo sujeito que ali se encontra. ${ }^{8}$

Nesse espaço tenebroso, quem representa o lugar do afeto são as mulheres, na sua maioria: uma das cegas e o menino que materna, a rapariga de óculos escuros, a secretária do médico e o cego de um olho só, que representa o narrador-Tirésias. Todas essas personagens preservam o lugar do afeto a partir da mediação da mulher do médico.

\footnotetext{
${ }^{8}$ Parte desse argumento sobre espaço/lugar origina-se em pesquisa desenvolvida por Izabel Brandão entre 2009-2011, em projeto financiado pelo $\mathrm{CNPq}$ já tendo aparecido em outras publicações: no livro Gênero e outros lugares: espaços interdisciplinares (BRANDÃO; ALBUQUERQUE [orgs.], 2009), em artigos publicados no Brasil e no exterior. Cf. referências completas ao final deste artigo.
} 
Pode-se juntar a essas personagens o casal de japoneses também, uma vez que, em certa medida, se resguardam pela língua estrangeira que continuam a falar naquele território de ninguém. Preservam, assim, um pouco de sua identidade deslocada da cultura hegemônica.

Complementarmente, o filme de Meirelles faz uma torção digna de nota: outra cena que mostra, mais uma vez através do olhar da mulher do médico, o desnudamento da paixão e do sexo fora do casamento, mas consentido entre o médico e rapariga de óculos escuros, cega como todos os que estão nesse "não-lugar". O olhar da mulher que vê a cena compartilha com o/a espectador/a a relação que se dá entre homem e mulher, sem uma reação de oposição dela - a mulher oficial - à situação entre seu marido e uma amante. Como naquele espaço ninguém vê nada, pouco interessa ao casal que faz sexo as reações dos outros, não fosse o fato de que, do lado de cá da tela, nós apreendemos a cena com o olhar que desliza da condição de voyeur à de perplexidade e admiração pelo encontro realizado em meio ao desencontro/desencanto apresentado em todo o filme.

Segundo Mulvey (2009 [1975]), o cinema contemporâneo não foge da questão da mulher na sociedade patriarcal. Nesse sentido, podemos dizer que o filme de Meirelles coloca a mulher do médico num papel que, normalmente, é delegado aos homens, inclusive numa cena como a descrita, em que o voyeurismo da personagem se confunde com o do público que assiste à cena. Pode-se afirmar, então, que a personagem da mulher do médico acaba por desmistificar a ideia de que as mulheres não estão nunca na posição de voyeur. $\mathrm{O}$ que se pode ainda dizer sobre isso é que seu olhar sob a cena de sexo entre seu marido e a outra mulher não se impõe de uma forma exibicionista nem conivente com a situação de traição. É possível, talvez, observar uma certa aquiescência dela com o que ocorre, por razões 
que apontam para a dureza da experiência vivida, ou uma crise no próprio relacionamento com o marido, ou simplesmente uma aceitação do fato diante do inevitável. Seu silêncio mais uma vez é testemunha de um assentimento de uma situação em que ela nada pode fazer. Ela é a única entre as mulheres que olha, mas não é olhada por mais ninguém (excetuando-se o espectador) e mesmo as mulheres estupradas, que são por ela olhadas, não podem ser colocadas na posição de objetos, como habitualmente Hollywood faz em seus filmes linha de frente. Se há uma condição de objeto no filme, isso aparece em todos os personagens, pois todos são objeto da exploração e descaso da sociedade.

Zygmunt Bauman nos ensina que "o medo e o mal são irmãos siameses" (2008, p. 74). De acordo com o sociólogo polonês, a iniquidade do "mal" reside no fato deste se colocar como ininteligível, inexplicável. Ao discutir a falhada aposta da modernidade no poder da razão, Bauman sinaliza para os perigos que rondam uma "racionalidade sóbria, intransigente, concentrada na tarefa" (2008, p. 84), já que somos insistentemente treinados a fechar os olhos e tapar os ouvidos para realidades que nos soam como desinteressantes. Tal fato é ricamente ilustrado pelo silêncio constrangedor que circunda experiências como Auschwitz, Hiroshima, Gulag e, mais recentemente, Guantánamo e Bagram. A partir desses fatos, não seria arriscado sustentar que "um medo genuína e irremediavelmente insustentável é o da invencibilidade do mal" (BAUMAN, 2008, p. 90).

Se o mal pode estar oculto em qualquer lugar, inexistindo marcas distintivas que o identifiquem, se todos, ocasionalmente, podem estar a seu serviço, se os estranhos e anônimos são constantemente fonte de desconfiança, o que poderá urdir laços de afeto e proximidade numa estrutura societária na qual parcerias não se fortalecem e a paranoia não se dissipa? 
No romance de Saramago, há "entre os cegos uma mulher que dava a impressão de estar ao mesmo tempo em toda parte, ajudando a carregar, fazendo como se guiasse os homens, coisa evidentemente impossível para uma cega [...]" (SARAMAGO, 1995, p. 91). A mulher do médico, imune à cegueira branca, guia o grupo central de personagens durante todo o enredo, conduzindo, assim, a narrativa.

Compete ao leitor/espectador um questionamento: o que sustenta o fato de que uma mulher é a única que mantém a capacidade de se confrontar com o horror, com o evento traumático que inscreve feridas na memória? Relançando a indagação: o que permite àquela que ocupa uma posição feminina ter um acesso mais direto ao Real que enuncia o que jamais deixa de existir?

As elaborações teóricas lacanianas, em vários momentos, referem-se às aproximações entre a mulher e o Real, insinuando que esta lida melhor com a lógica do inconsciente, encarna com mais desenvoltura a ideia de liberdade, uma vez que seu gozo não se subjuga totalmente à ordem fálica. E é sabido que, nas formações linguageiras, o Real comanda o discurso; isto é, as palavras são tecidas a partir do não sentido do Real. $\mathrm{Na}$ fala da mulher do médico, tem-se: "descemos todos os degraus da indignidade [...] agora somos todos iguais perante o mal e o bem, [...] o certo e o errado são apenas modos diferentes de entender a nossa relação com os outros [...]" (SARAMAGO, 1995, p. 262, grifos nossos).

No que diz respeito à posição feminina, Slavoj Zizek vem nos alertar que "a mulher não se encontra inteiramente submetida ao nexo da causalidade; com ela quebra-se o encadeamento linear da causalidade" (2006, p. 55), traço de estrutura que marca, indelevelmente, a ordem simbólica. A mulher configura-se, portanto, como uma distorção ou inflexão do discurso masculino, ora ocupando o lugar de sublime objeto (amor cortês), 
ora resvalando para a degradação, o que a identifica, invariavelmente, com a perda narcísica do ideal do eu masculino. O fato de ser apontada como insígnia de uma completude perdida, puro vazio de subjetividade, possibilita-lhe manter uma ética que persegue o desejo, tornando-se "a cínica capaz de detectar, nas declarações pomposas sobre o bem-estar público, os motivos privados daqueles que os emitem" (ZIZEK, 2006, p. 93). A partir disso, pode-se compreender o pavor diante da incoerência do feminino, pois, como nos diz a rapariga de óculos escuros: "Dentro de nós tem há uma coisa que não tem nome, essa coisa é o que somos" (SARAMAGO, 1995, p. 93 - grifos nossos).

Por outro lado, reportando-nos a Virginia Woolf, em seu célebre Um teto todo seu (1991 [1928], p.55-56), a escritora observa que, na literatura do passado, as mulheres sempre tiveram um lugar de destaque, e fala de personagens como

Clitemnestra, Antígona, Cleópatra, Lady Macbeth, Fedra, Créssida, Rosalinda, Desdêmona e a duquesa de Malfi, entre os dramaturgos; entre os prosadores, Millamant, Clarissa, Becky Sharp, Ana Karênina, Emma Bovary, Mme de Guermantes -, os nomes afluem à mente em bandos, e não lembram nem um pouco mulheres "carentes de personalidade e caráter". De fato, se a mulher só existisse na ficção escrita pelos homens, poderíamos imaginá-la como uma pessoa da maior importância: muito versátil; heróica e mesquinha; admirável e sórdida; infinitamente bela e medonha ao extremo; tão grande quanto o homem e até maior, para alguns. Mas isso é a mulher na ficção. Na realidade, como assinala o professor Trevelyan, ela era trancafiada, surrada e atirada no quarto.

Saramago tece o seu fio narrativo colocando, na personagem da mulher do médico, uma mulher que vê e que percebe o que há de errado no contexto em que 
está vivendo e busca constituir a sua existência dentro do universo da cegueira como aquela que pode fazer algo pelo outro. Diferentemente das suas antecessoras literárias citadas por Woolf, essa mulher contemporânea não é só de papel. A conjuntura mudou, o tempo é outro, mas, seguindo o texto woolfiano e suplementando-o historicamente, a mulher da ficção de Saramago é "versátil; heróica e mesquinha; admirável e sórdida; infinitamente bela e medonha", mas, como mulher contemporânea, continua aprisionada, violentada e estuprada, conforme a narrativa expõe cruamente. Mudaram os tempos, mas a percepção do que representa os sujeitos do sexo feminino ocupando essa posição mudou muito pouco.

O filósofo franco-argelino Jacques Derrida - ao discorrer sobre os estrangeiros, exilados, deportados, expulsos da cultura, e o conceito de hospitalidade aponta para a língua, para a possibilidade discursiva como a ponte passível de estabelecer um diálogo entre eu e o outro que me ameaça: o knésos, o estrangeiro. A palavra seria, pois, a última pátria e morada, resto de pertencimento à comunidade humana (DERRIDA, 2003, p. 79). Situando-se o problema da hospitalidade e do acolhimento como coextensivo ao dilema ético, entende-se o que significam as palavras da mulher do médico quando esta assevera que "é um velho problema da humanidade, esse de passar ao lado dos mortos e não os ver [...]" (SARAMAGO, 1995, p. 284). Pode-se vislumbrar, na narrativa de Saramago, um tênue fio de Esperança (última entidade a sair da Caixa de Pandora), o que nos incita a edificar uma vida onde Eros e Tânatos se situem como forças complementares, o que tornaria menos dolorosos o exílio e a errância do ser de desejo pelas veredas da existência.

Em texto inédito sobre tradução, Sandra Almeida (2010) argumenta que a passagem de uma língua para outra implica a "experiência da hospitalidade[:...]'convite, a 
acolhida, o asilo, o albergamento passam pela língua ou pelo endereçamento ao outro', pois 'a língua é hospitalidade', como lembra Derrida". A partir dessa percepção de tradução - de um meio (a literatura) para outro (o cinema) -, podemos apreender a noção de acolhimento no sentido de hospitalidade. Assim, é possível dizer que a tradução fílmica de Meirelles "acolheu" o romance de Saramago, o que pode ser visto simbolicamente ilustrado através das imagens de purificação trazidas pela água - de chuva, do banho - que "inundam" as cenas finais do filme.

Mesmo reconhecendo as restrições do cinema em relação à literatura, José Saramago ficou satisfeito com a adaptação de sua obra. Indagado se o filme foi "fiel" ao seu romance, o autor rebateu, em uma de suas entrevistas sobre o filme: "Acho que isso não existe. O que importa é que foi eficaz". De acordo com escritor, pior seria se a "fidelidade" ao livro tivesse sido excessiva, afinal, "um realizador é um criador, não é um mero copista”.

Concordamos com Thaïs Flores Diniz (1999; 2005), quando a pesquisadora destaca a ampliação da noção de tradução para além do âmbito da linguagem e da interpretação. Segundo ela, os livros e filmes adaptados fazem parte de um contexto histórico e cultural. Por isso, a adaptação, assim como a tradução, leva em conta as referências de ordem externa, responsáveis por impregnar os signos literários e fílmicos, originando uma leitura intertextual e multifacetada.

A metáfora da cegueira utilizada por Saramago em seu Ensaio sobre a cegueira, e traduzida/transposta por Meirelles para o cinema, em Blindness, aponta para a visualidade, a pregnância da imagem no mundo contemporâneo. A epígrafe "Se podes olhar, vê. Se podes ver, repara", do autor português, é como uma lente de aumento nos instando a olhar em volta e a reparar com cuidado na existência do outro, que somos nós mesmos. 


\section{Referências}

ALMEIDA, Sandra Regina Goulart. "Outras traduções: Gayatri Chakravorty Spivak e a crítica pós-colonial e cultural”, 2010, 16p. Texto inédito (srga@ufmg.br).

ARANTES, Silvana. Invasões bárbaras. Folha de S. Paulo. São Paulo, 01 mai. 2008, Cotidiano, p. 6.

AUGÉ, Marc. Não-Lugares: introdução a uma antropologia da supermodernidade. Trad. Fernando Cornacchia. Campinas: Papirus, 1994.

BARTHES, Roland et al. Análise Estrutural da Narrativa. Maria Zélia Barbosa Pinto. São Paulo: Vozes, 1976

BAUMAN, Zygmunt. Medo líquido. Trad. Carlos Alberto Medeiros. Rio de Janeiro: Jorge Zahar, 2008.

BÍBLIA DE JERUSALÉM. Trad. Euclides Martins Balancini et al. São Paulo: Paulinas, 1985.

BLINDNESS [Ensaio sobre a cegueira], o filme. Direção: Fernando Meirelles. Produção: Niv Fichman. Local: Brasil, Canadá e Japão, distribuição: Miramax e Focus Feature. Produtora: Fox Filmes, 2008.

BRANDÃO, Izabel. Dimensões políticas e afetivas em Maru, da escritora su-africana Bessie Head. In: BRANDÃO, Izabel; ALBUQUERQUE, Fátima (orgs.). Gênero e outros lugares: poéticas e espaços interdisciplinares. Maceió: Edufal, 2009, p. 117-126.

BRANDÃO, Izabel; ALBUQUERQUE, Fátima (orgs.). Gênero e outros lugares: poéticas e espaços interdisciplinares. Maceió: Edufal, 2009. 
BRANDÃO, Izabel. Dimensões políticas e afetivas do conceito de espaço/lugar: reflexões a partir de textos literários do século XX. In: Revista Latino Americana de Geografia e Gênero. Ponta Grossa: vol. 2, no 2, p.100-107, ago-dez. 2011.

BRANDÃO, Izabel. Kangaroo: Lawrence's homeless hero in search of place. In: D. H. L Review. Vol 36, Number 1, 2011, p. 14-30.

CAMPBELL, Joseph. The Masks of God - Occidental Mythology. New York: Penguin Books, 1987 [1965].

DERRIDA, Jacques. Anne Dufourmantelle convida Jacques Derrida a falar da hospitalidade. Trad. Antonio Romane. São Paulo: Escuta, 2003.

DINIZ, Thaïs Flores Nogueira. Literatura e cinema: da semiótica à tradução cultural. Ouro Preto: Editora UFOP, 1999.

DINIZ, Thaïs Flores Nogueira. Literatura e cinema: tradução, hipertextualidade, reciclagem. Belo Horizonte: Faculdade de Letras da UFMG, 2005.

FOUCAULT, M. Outros espaços [1984]. In: FOUCAULT, M. Ditos e escritos III. Estética, Literatura e pintura, música e cinema. Trad. Inês A. D. Barbosa. Rio de Janeiro: Forense Universitária, 2001, p.411-422.

FREUD, Sigmund. O mal-estar na civilização. In: Obras completas de Sigmund Freud. Trad. José Octávio de Aguiar Abreu. Rio de Janeiro: Imago, ESB, 1976, v. 21.

JULIEN, Philippe. Psicose, neurose, perversão: uma leitura de Jacques Lacan. Trad. Procopio Abreu. Rio de Janeiro: Companhia de Freud, 2002.

METZ, Christian. A Significação no Cinema. Tradutor: JeanClaude Bernadet. 2. ed. São Paulo:Ed Perspectiva, 1977. 
MULVEY, Laura. Visual and other Pleasures. Houndmills:

Palgrave Macmillan, 2009.

NEUMANN, E. The Great Mother - an analysis of the archetype. Transl. by Ralph Manheim. London: Routledge and Kegan Paul, 1963.

SARAMAGO, José. Caminhamos pela vida como cegos da razão. In <<http://blogdeblindness.blogspot.com.br/>> Acesso em 21 de novembro de 2009.

SARAMAGO, José. A humanidade não merece a vida. Folha de S. Paulo, São Paulo, Cotidiano, p. 5, 29 nov. 2008.

SARAMAGO, José. As intermitências da morte. São Paulo: Companhia das Letras, 2005.

SARAMAGO, José. Ensaio sobre a cegueira. São Paulo: Companhia das Letras, 1995.

SILVA, Almir Guilhermino da. Dom Casmurro: a encenação de um julgamento: na adaptação cinematográfica de Moacyr Góes e de Paulo César Saraceni. Maceió: Edufal, 2008.

TOMAZ, Jerzuí M. T. O corpo e afeto na escrita de Lya Luft. Maceió: Edufal, 2009.

WOOLF, Virginia. Um teto todo seu. Trad. Vera Ribeiro. Rio de Janeiro: Nova fronteira, 1991.

ZIZEK, SLAVOJ. As metástases do gozo: seis ensaios sobre a mulher e a causalidade. Trad. Miguel Serras Pereira. Lisboa: Relógio D’Água, 2006.

[Recebido em 18 maio de 2013

e aceito para publicação em 16 de julho de 2013] 